\title{
A study to determine if dried moringa leaf powder is an acceptable supplement to combine with maize meal for Malawian children
}

\author{
L. McLellan, J. Mckenzie and M. E. Clapham \\ Health Sciences, Queen Margaret University, Edinburgh EH21 6UU, UK
}

The population of Malawi is just over 14 million $^{(1)}$. The staple crop in Malawi is maize, but in the past 10 years Malawi has experienced at least five severe droughts and a number of floods that have led to periods of famine ${ }^{(2)}$. As a consequence of famine, $5 \%$ of the children are wasted or severely malnourished and $22 \%$ are underweight or malnourished ${ }^{(3)}$. A sustainable approach to preventing malnutrition has become increasingly important in recent years with climate change, population pressures and global economic decline. It has been suggested that dried moringa leaves (Moringa oleifera), a locally grown product has the potential to go someway towards meeting the needs of Malawian children, as it is relatively rich in protein and micronutrients; however, it apparently has a bitter taste and an unfamiliar green colour.

One-hundred-and-twenty orphaned children less than 6 years of age were randomly split into 3 groups. Over a course of 6 weeks they were each provided a porridge meal everyday. One group was given a standard maize meal porridge (Likuni Phala), a second group was given a maize/moringa/soya mix and the third group was given a maize and moringa mix. The porridges had a similar protein and energy content. Using plate wastage, questionnaires and observations, a level of acceptability for each porridge was determined. Cooks were also asked to evaluate the practicalities of using Moringa in the porridge.

Analysis showed that in the first 3 weeks of the trial, the moringa and maize porridge (group 3) was less acceptable than the other two porridges. However, by week 6 there was no significant difference between the acceptability of the porridge mixes. This was reflected in both questionnaires responses and plate wastage. The cooks observed that although the three porridges required different cooking methods, all were acceptable.

Due to the high level of acceptance in the final weeks of the trial, it is concluded that moringa leaf powder has the potential to be a very important source of local sustainable nutrition in the Malawian diet.

1. Central Intelligence Agency (2009) Available from: https://www.cia.gov/library/pulications/the-world-factbook/ (accessed October 2009).

2. World Food Programme (2009) Country Portfolio Evaluation of WFP Assistance to Malawi Final Report.

3. UNICEF (2006) Malawi. http://www.unicef.org/infobycountry/malawi-2424.html (accessed October 2009). 